\title{
Opinion \\ Biodiesel Production from Waste Oils: A South African Outlook
}

\author{
Ella Cebisa Linganiso ${ }^{1,2,3} * \mathbb{D}$, Boitumelo Tlhaole ${ }^{2} \mathbb{D}$, Lindokuhle Precious Magagula ${ }^{2} \mathbb{D}$, Silas $^{\text {Dziike }}{ }^{4}$, \\ Linda Zikhona Linganiso ${ }^{5} \mathbb{D}$, Tshwafo Elias Motaung ${ }^{3,6} \mathbb{D}$, Nosipho Moloto ${ }^{2} \mathbb{D}$ and Zikhona Nobuntu Tetana ${ }^{1,2} \mathbb{D}$
}

1 Microscopy and Microanalysis Unit, University of the Witwatersrand, Johannesburg 2050, South Africa; Zikhona.Tetana@wits.ac.za

2 Molecular Sciences Institute, School of Chemistry, University of the Witwatersrand, Johannesburg 2050, South Africa; Boitumelo.Tlhaole1@students.wits.ac.za (B.T.); Lindokuhle.Magagula@students.wits.ac.za (L.P.M.); nosipho.moloto@wits.ac.za (N.M.)

3 Department of Chemistry, Sefako Makgatho Health Science University, City of Tshwane 0204, South Africa; motaute1@unisa.ac.za

4 Independent Researcher, Johannesburg 2090, South Africa; dziikes@outlook.com

5 Research \& Postgraduate Support, Durban University of Technology, Durban 4000, South Africa; researchdirector@dut.ac.za

6 Department of Chemistry, School of Science in the College of Science Engineering and Technology, University of South Africa, City of Tshwane 0003, South Africa

* Correspondence: linganisoella@gmail.com or Cebisa.Linganiso@wits.ac.za

check for updates

Citation: Linganiso, E.C.; Tlhaole, B.; Magagula, L.P.; Dziike, S.; Linganiso, L.Z.; Motaung, T.E.; Moloto, N.; Tetana, Z.N. Biodiesel Production from Waste Oils: A South African Outlook. Sustainability 2022, 14, 1983. https://doi.org/10.3390/su14041983

Academic Editor: Yusuf G. Adewuyi

Received: 14 January 2022

Accepted: 1 February 2022

Published: 10 February 2022

Publisher's Note: MDPI stays neutral with regard to jurisdictional claims in published maps and institutional affiliations.

Copyright: (C) 2022 by the authors. Licensee MDPI, Basel, Switzerland. This article is an open access article distributed under the terms and conditions of the Creative Commons Attribution (CC BY) license (https:// creativecommons.org/licenses/by/ $4.0 /)$.

\begin{abstract}
The viability of large-scale biodiesel production ultimately boils down to its cost of commercialisation despite other very important factors such as the negative environmental and health effects caused by the direct combustion of fossil diesel. How much each country's economy will be influenced by the production of biodiesel will be determined by the commitment of various stakeholders to the much-needed transition from petroleum-based resources to renewable resources. Biodiesel production is largely determined by the cost of the feedstock $(>70 \%)$ and this review focuses on the use of waste oil resources as biodiesel feedstock with a special focus on waste cooking oil (WCO). Generating value from waste oil provides an alternative waste management route as well as a positive environmental and economic contribution. The transesterification process for biodiesel production, its catalysis and some important technical and economic aspects are covered in this communication with a special focus on the South African framework. An overview of the current research and its implications going forward is discussed.
\end{abstract}

Keywords: biodiesel production; waste cooking oil; transesterification; South Africa

\section{Introduction}

South Africa (SA) has about 0.95 thousand barrels per day in crude oil reserves as from September 2021, according to World Data Atlas [1]. SA's daily crude oil production sits at approximately 0.55 million barrels per day as of December 2020, while petroleum consumption is approximately 0.49 million barrels per day according to the same reference [1]. Approximately $64 \%$ of our daily oil consumption is imported oil. This makes the SA economy quite vulnerable to the fluctuating oil prices in the world, and yet oil demand continues to increase as the industrial sector and civilization expands. Dwindling natural resources accompanied by increasing concerns about the negative environmental impact of greenhouse gas emissions have encouraged the exploration of alternative energy sources.

Derived from renewable resources such as vegetable oils and animal fats, biodiesel is a biodegradable and non-toxic fuel with low emission profiles and it can be used in existing diesel engines without any modification [2]. It is currently one of the most promising alternative energy sources and a clean substitute for commercial diesel. Biodiesel is defined as a fuel that contains mono-alkyl esters of long chain fatty acids acquired from vegetable oils or animal fats, designated "B100" whose properties meet the American Society for 
Testing and Materials (ASTM) D6751 and European (EN) 14214 standards [3]. Biodiesel has been gaining preferment as a viable alternative to petroleum-based diesel over the past decade with the world's leading producers being the United States of America (6.9 billion litres), Brazil ( 5.4 billion litres), Indonesia (4 billion litres), Germany (3.5 billion litres) and Argentina (2.8 billion litres) in 2018 [4]. The government of SA has shown interest in biodiesel production from vegetable oil over the past years, and the country already has commercial producers of both biodiesel (B100) and biodiesel blends with fossil diesel. This is viewed as an approach to expand the agricultural sector and create new jobs specifically in the rural areas of the country.

The key critical questions for biodiesel production are the cost of raw materials and the inadequate availability of vegetable oils. This becomes especially important in developing countries where vegetable oil is highly needed for food. SA, having suffered drought in recent years, cannot confidently lead a transition from fossil diesel to biodiesel using large quantities of vegetable oils. Approximately $75 \%$ of the total manufacturing cost of biodiesel is attributed to the vegetable oil feedstock, which leads to biodiesel production costs reaching almost 1.5 times higher than commercial diesel costs [5]. On the other hand, the waste cooking oil (WCO) price is about 2-3 times cheaper than virgin vegetable oil, which can considerably reduce the biodiesel cost of production [6]. With increasing food consumption, a large amount of generated WCO, some of which is carelessly dumped, is directly contributing to environmental pollution. WCO can be easily collected from the hospitality industry (hotels, restaurants and fast-food chains) as this industry produces large quantities of WCO and is obligated by legislation to dispose of waste responsibly [7]. Used oil generators, and of waste in general, are required by law under the Waste Act No. 59 of 2008 to ensure that their waste is responsibly managed and disposed of. Regulation 5(1) of the National Waste Management Regulations, 2012 stipulates that any person who generates hazardous waste in excess of $20 \mathrm{~kg}$ per day must apply to the Department of Environmental Affairs to be registered on the National Waste Information System (SAWIS), and to report on the volumes generated and taken away for recycling. Regulation 12 further stipulates that anyone who fails to comply with the regulations is guilty of an offence and may be liable upon conviction to imprisonment for a period not exceeding 15 years or to a fine or to both a fine and imprisonment [7].

The current SA waste legislation does not put pressure on residential/household waste generators, and the majority of SA citizens are not knowledgeable about oil recycling or its negative environmental impact when carelessly disposed of. Advances in waste oil recycling, including the purchasing of waste oil from the hospitality industry and citizens, and using the oil through biodiesel production would add economic value to the country, while reducing environmental pollution [8]. Recycling the oil would prevent a $2.8 \mathrm{~kg}$ carbon emission per $\mathrm{kg}$ of waste oil dumped into the environment, which translates to a significant contribution towards a green environment and green economy [9]. This would reduce $\mathrm{CO}_{2}$, particulate matter and other greenhouse gases, as the carbon contained in biomass-derived fuel is largely biogenic and renewable. WCO use in biodiesel production can reduce the manufacturing costs of biodiesel by $60-90 \%[10,11]$. In an effort to produce high quality biodiesel at lower costs, researchers are using various novel processes to decrease the reaction time, amount of alcohol, catalyst, and particularly reaction temperature [12-14]. According to Dimian and Kiss (2019), Germany produced 1.5 million tons of biodiesel from used cooking oil in 2017, which accounted for approximately half of their biodiesel production [14]. If SA can highly embrace the use of WCO for biodiesel production, the country would gain more value from the high financial implications of crop farming and seed processing while reducing competition for fresh oil consumption and farmlands. Much more economic investments towards locally based production would be achieved, reducing the investments towards crude oil imports while ultimately dodging or at least reducing fossil diesel's catastrophic climatic effects. The following communication will review the various stages of biodiesel production, important factors contributing to its admiration and its relevance to the SA economy. 


\section{Pre-Treatment of WCO Feedstock}

As mentioned in the introduction, WCO can easily be obtained from the hospitality industry, which is amongst the sectors required by legislation to dispose of their waste responsibly. Many WCO generating companies have partnered with waste oil recycling companies that collect their waste oil at agreed specific times and locations. The collected oil is then pre-treated in order to remove solid particles/residues (filtering), excess moisture (heating), and is tested for quality and free fatty acid (FFA) content. There are some vital characteristic properties that determine whether or not WCO can be employed as feed for biodiesel: acid value (AV), water content and saponification value $[15,16]$. The $\mathrm{AV}$ of waste oil can be indicative of its FFA content. A high FFA content promotes the formation of soap thus decreasing the efficiency of the transesterification process [15,17-19]. Successful transesterification needs a maximum FFA content of about 3\% [15]. Water in the oil also encourages more soap formation thus its content needs to be determined [18]. The saponification value, which is the amount of base $(\mathrm{NaOH} / \mathrm{KOH})$ in milligrams required to turn $1 \mathrm{~g}$ of oil into soap, is another property used to estimate the quality of WCO [20]. Knowing these properties can help design an efficient biodiesel production process. The density and viscosity of the feedstock can also be determined but could be more important in the analysis of biodiesel than the feedstock [16].

A problem usually encountered with WCO as feedstock in biodiesel production is the presence of unwanted solid impurities and a high FFA and water content [15]. The presence of moisture can hydrolyse the triglyceride in the waste oil to form FFA (Equation (1)) and the FFAs react with the base catalyst to form soap as mentioned before (Equation (2)). Therefore, WCO must undergo pre-treatment prior to transesterification. The solid impurities are removed by washing off with hot water, centrifugation and filtration [15]. The moisture is eliminated by distillation or by heating the oil above $100{ }^{\circ} \mathrm{C}[15,18]$. To reduce the high FFA content, WCO can be subjected to acid catalysed esterification prior to transesterification [17-19], pre-treated with an adsorbent [21] and passed through an acid ion-exchange resin [22].

$$
\begin{gathered}
\underset{\text { Triglyceride }}{\mathrm{C}_{3} \mathrm{H}_{5}(\mathrm{OCOR})_{3}}+\underset{\text { Water }}{\mathrm{H}_{2} \mathrm{O}} \leftrightarrow \underset{\text { Diglyceride }}{\mathrm{C}_{3} \mathrm{H}_{5}(\mathrm{OH})(\mathrm{OCOR})_{2}}+\underset{\text { Ester }}{\mathrm{RCOOH}} \\
\underset{\text { FFA }}{\mathrm{RCOH}}+\underset{\text { Base }}{\mathrm{NaOH}} \leftrightarrow \underset{\text { Soap }}{\mathrm{RCOONa}}+\mathrm{H}_{2} \mathrm{O}
\end{gathered}
$$

Acid esterification is widely used where the FFA in the oil is treated with alcohol in the presence of a catalyst (Equation (3)) [18,19]. Sahar et al. (2019) investigated the acid catalysis of WCO by employing $\mathrm{HCl}, \mathrm{H}_{2} \mathrm{SO}_{4}$ and $\mathrm{H}_{3} \mathrm{PO}_{4}$ as catalysts [19]. They reported that the most efficient esterification was in $\mathrm{H}_{2} \mathrm{SO}_{4}$, which was able to reduce the FFA content by approximately $88.8 \%$ with a $1: 2.5$ methanol: oil ratio at $60{ }^{\circ} \mathrm{C}$.

$$
\mathrm{RCOOH}+\mathrm{R}^{\prime} \mathrm{OH} \stackrel{\text { Acid }}{\leftrightarrow} \mathrm{RCOOR}^{\prime}+\mathrm{H}_{2} \mathrm{O}
$$

\section{Biodiesel Production}

The commercial production of biodiesel is generally established through conventional or supercritical heating methods. Some of the regularly used methods include pyrolysis, micro-emulsions, dilution, reactive and catalytic distillation, and the transesterification of oils to esters $[23,24]$. The transesterification method has been shown to be the simplest and most cost-effective method for biodiesel production with biodiesel properties matching those of fossil diesel. The methods used for the transesterification of organic feedstock to produce biodiesel include conventional heating with acid, base catalysts and co-solvents; sub- and super-critical methanol conditions with co-solvents and without a catalyst; an enzymatic method using lipases; ultrasonic and hydrodynamic cavitation; and microwave irradiation with acid, base and heterogeneous catalysts [25]. 


\subsection{Transesterification Process}

Transesterification is a chemical reaction in which an ester (oil) is reacted with an alcohol to produce an alkyl ester (biodiesel) and glycerol (Scheme 1) [26]. In this reversible reaction, one molar equivalent of triglyceride (oil) reacts with three molar equivalents of alcohol in the presence of a catalyst to form three molar equivalents of alkyl ester and one molar equivalent of glycerol:<smiles></smiles>

Triglyceride
Alcohol

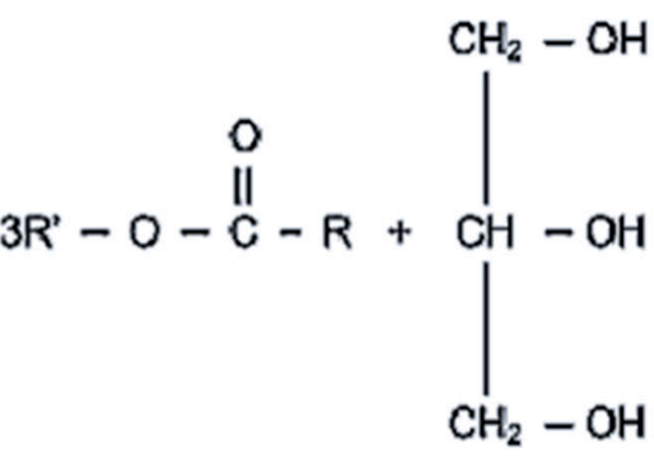

Alcyl ester (Biodiesel)
Glycerol

Scheme 1. Transesterification process for biodiesel production. Adapted with permission from [26], Copyright $\{2022\}$, American Chemical Society.

The general alkali-catalysed transesterification mechanism is explained in Figure 1 [27]. In the first step, the base catalyst reacts with the alcohol to produce a nucleophilic alkoxide and a protonated base catalyst (1). The second step is a nucleophilic attack of the alkoxide at the carbonyl carbon in the triglyceride forming an unstable tetrahedral intermediate (2). This intermediate dissociates into an alkyl ester and a diglyceride anion (3). During the final step, the base catalyst is deprotonated by the diglyceride anion to form a stable diglyceride molecule thus regenerating the base catalyst (4). The regenerated catalyst restarts the cycle with another glyceride molecule (di- or monoglyceride) to produce a mixture of alkyl esters and glycerol.

\subsection{The Role of Alcohol}

Alcohol plays an important role as an acyl acceptor in the transesterification reaction. Methanol is currently the widely used alcohol, but ethanol has also proven to be a viable alternative $[28,29]$. Other short chain alcohols such as propanol, butanol, isopropanol, t-butanol and octanol can be applied; however, they are costly. Longer chains are avoided due to the steric hindrance effect [29].

Methanol is commercially used because the transesterification reaction is faster with it, the base catalyst $(\mathrm{NaOH})$ easily dissolves in it, and it can be easily recycled once the reaction is complete [28]. The concern with methanol is that most of it is derived from natural gas which makes it non-renewable $[28,29]$. Ethanol on the other hand can be obtained from the fermentation processes of biomass, making it a renewable alternative [29]. Oil is also more soluble in ethanol than methanol and the alkyl esters (fatty acid ethyl estersFAEE) produced could improve the cold starts and storage conditions of biodiesel [29]; however, the transesterification process in ethanol is usually slower and the formation of stable emulsions complicates the separation of the biodiesel and glycerol. Researchers have investigated using a mixture of methanol and ethanol to combine the advantageous benefits of both alcohols in biodiesel production from waste oil $[29,30]$. Issariyakul et al. (2007) reported the use of a methanol-ethanol mixture in biodiesel production from waste fryer grease to enhance the solvent property of the ethanol and the equilibrium conversion 
of the methanol [30]. Lam and Lee (2011) reported the use of a methanol-ethanol mixture and a breakthrough catalyst to produce a greener biodiesel fuel from waste cooking oil [29]. They reported an $81.4 \%$ yield of biodiesel from a 9:6:1 methanol to ethanol to oil molar ratio, a $150{ }^{\circ} \mathrm{C}$ reaction temperature, $6 \mathrm{wt} \%$ catalyst and $1 \mathrm{~h}$ reaction time, which is comparable to biodiesel yields obtained when using methanol only, and much higher than biodiesel yields previously obtained when using ethanol only [29].

(1)

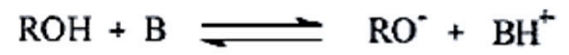

(2)<smiles>[R]C(=O)OCC(COC([R1])=O)OC[C@H](COC([R])[R])OC([R2])=O</smiles>

(3)<smiles>[R1]C(=O)OCC(COC([R])C1([R1])CO1)OC([R])=O</smiles>

(4)<smiles>[R3]C(=O)OCC(C[O-])OC([R12])=O</smiles><smiles>[R]C(=O)OCC(C[O-])OC([R])=O</smiles><smiles>[R]OC([R])=O</smiles>

Figure 1. Mechanism of alkali-catalysed transesterification of oil. Adapted with permission from [26], Copyright $\{2022\}$, American Chemical Society.

\subsection{Catalysis}

\subsubsection{Homogeneous Acid and Base Catalysts}

Homogeneous chemical catalysts are commonly utilized in industrial biodiesel production because of their higher level of efficiency, short reaction times, high selectivity, operation at low temperatures, and effortless optimization of activity [31-33]. Homogeneous catalysts are divided into two sub-groups, namely, acid and base catalysts [32,34]. Since homogeneous base catalysts are only suitable for oils with an FFA content of less than $3 \mathrm{wt} \%$, homogeneous acid catalysts are usually utilized before base catalysts in order to reduce the FFA content in the oil feedstock, such that soap formation is minimized. This process is known as pre-esterification [34,35]. The most common employed homogeneous base catalysts are alkaline liquids including hydroxides (sodium hydroxide $(\mathrm{NaOH})$ and potassium hydroxide $(\mathrm{KOH})$ ) and methoxides (sodium methoxide $\left(\mathrm{CH}_{3} \mathrm{ONa}\right)$ and potassium methoxides $\left.\left(\mathrm{CH}_{3} \mathrm{OK}\right)\right)$, whereas the most common homogeneous acid catalysts are nitric acid $\mathrm{HNO}_{3}$, hydrochloric acid $(\mathrm{HCl})$, and sulphuric acid $\left(\mathrm{H}_{2} \mathrm{SO}_{4}\right)[32,33,36-38]$.

Homogeneous acid catalysts are not industrially used as much as homogeneous base catalysts for biodiesel production due to the harsher reaction conditions requirements (high 
temperature and pressure), catalyst corrosion, the requirement for a high alcohol ratio to oil, and longer reaction times [34]. Thus, homogeneous acid catalysts are employed in the two-step (acid first and alkali next) transesterification method in order to decrease the FFA content of an oil feedstock to an acceptable level before the usual base-catalysed transesterification process [38-40]. Ramadhas et al. (2005) used the two-step method to prepare biodiesel from crude rubber seed oil with a 17\% FFA content, which was reduced by a sulphuric acid $\left(\mathrm{H}_{2} \mathrm{SO}_{4}\right)$ esterification method to less than $2 \%$. This was followed by an alkali $(\mathrm{NaOH})$ transesterification process whereby the products of the first step were converted to mono-esters and glycerol [41]. The authors, through this two-step method, were able to produce biodiesel with properties that were comparable to ASTM standards and their method was reported to reduce the overall cost of biodiesel production due to the use of low-cost unrefined non-edible oils [41].

Homogeneous base catalysts are commonly applied industrially for biodiesel production since base-catalysed reactions are faster compared to acid-catalysed reactions, have high yields, mild reaction conditions and the most commonly used base catalysts are available at a low cost [42-44]. In homogeneous base-catalysed biodiesel production, the chosen feedstock (WCO, refining cooking oil, animal fats, edible or non-edible vegetable oil, etc.) is reacted with an appropriate alcohol such as methanol or ethanol to go through transesterification in the presence of a homogeneous catalyst [31,32,34]. These catalysts have been used in several conventional and non-conventional biodiesel production processes including the use of $\mathrm{KOH}$ for the production of biodiesel from WCO in a semi-industrial pilot micro-reactor with a fatty acid methyl ester (FAME) percentage of $99.65 \%$ by Mohadesi et al. (2019) [31]. The use of potassium methoxide for biodiesel production from soybean oil and dimethyl carbonate with a FAME percentage of $91 \%$ was reported by Celante et al. (2018) [36]. KOH has also been used in the production of biodiesel from Elaeagnus angustifolia L. seed as a novel waste feedstock [45].

Product recovery becomes difficult in a homogeneous base-catalysed biodiesel production process if the FFA content of the feedstock is high. In such an event, the base catalyst may react with the FFA and take the saponification route, forming a soap [32,34]. The formed soap inhibits the separation of biodiesel and glycerine, affecting the overall quality of the biodiesel and increasing the processing costs [40,42]. Various methods have been used to deal with this issue including the use of the two-step (acid first and alkali next) transesterification method mentioned earlier. In this method, an acid catalyst is applied first to convert the FFA to methyl esters before base catalysis [32,45-47]. Other methods such as the incorporation of a heterogeneous catalyst in a homogeneous base catalyst and using a carbon-based support material have been explored. Mohadesi et al. (2020) used a $\mathrm{KOH} /$ Clinoptilolite catalyst in a pilot of a microreactor for biodiesel production from waste cooking oil [42]. They were able to produce biodiesel with a purity of $97.45 \%$ at a $65{ }^{\circ} \mathrm{C}$ reaction temperature, $13.4 \mathrm{~min}, 8.1 \mathrm{wt} \%$ catalyst, and 2.25:1 oil to methanol ratio [42]. Pisitpong et al. (2014) used $\mathrm{KOH}$ loaded on a $\mathrm{ZrO}_{2}$ catalyst in a batch reactor for biodiesel production from palm oil [48]. In this study, over a $99 \%$ methyl ester content was achieved at $60{ }^{\circ} \mathrm{C}, 2 \mathrm{~h}, 20 \mathrm{wt} \%$ potassium loading over $\mathrm{ZrO}_{2}, 5 \mathrm{wt} \%$ catalyst, $15: 1$ methanol to oil ratio, $300 \mathrm{rpm}$ stirrer speed, and 10-20 mesh size catalyst. Their biodiesel had properties that satisfied the EN 14214 specifications and the activity of the catalyst used was attributed to the $\mathrm{K}_{2} \mathrm{O}$ active phase and its basic properties [48]. Sakusem and Manophana (2017) used a lime catalyst and sodium hydroxide $(\mathrm{CaO} / \mathrm{NaOH})$ for the development of biodiesel from vegetable oils [49]. They reported a high biodiesel yield of $86.3 \%$ at a $\mathrm{CaO}$ to $\mathrm{NaOH}$ ratio of 3:1 [49]. Baroutian et al. (2010) used a $\mathrm{KOH}$ supported AC solid base catalyst for biodiesel synthesis from palm oil [50]. A biodiesel yield of $98.03 \%$ was reported for optimized transesterification conditions and its properties met the ASTM standard [50].

\subsubsection{Ionic Liquids}

The use of ionic liquids (ILs) as catalysts, co-solvents, or extracting solvents have recently attracted attention in biodiesel production [51]. ILs are organic salts consisting 
of various cations and anions, in which cations are organic and anions are either organic or inorganic in nature $[52,53]$. They have melting points around or below the ambient temperature [52,53]. ILs have properties such as good thermal and chemical stability, non-corrosiveness, low vapor pressure, an ability to dissolve a large range of organic and inorganic products, high catalytic activity, ease of separation, and they produce high purity products $[51,54,55]$. Other properties include the modification of the hydrophobic and hydrophilic nature of ILs by altering the anions and cations, their reusability and recyclability, and they are also quite easy and safe to handle [56,57]. Nitrogen-containing ILs such as alkylammonium, $N, N^{\prime}$-dialkylimidazolium, $N$-alkylpyridinium, and $N, N^{\prime}$-pyrrolidinium and phosphorous-containing ILs such as alkylphosphonium are the most common ILs [51].

ILs can be used as acidic or basic catalysts in the production of biodiesel during onestep or two-step processes. Acid ILs' catalysts can be used for both the esterification of FFA and the transesterification of triacylglycerols and because ILs are made of a different grouping of anions and cations, the highest product yields have been reported for ILs with higher acidity [51]. Ullah et al. (2015) investigated the use of three different acidic (Brønsted) ionic liquids, $\mathrm{BMIMHSO}_{4}, \mathrm{BIMHSO}_{4}$, and $\mathrm{MIMHSO}_{4}$, as catalysts to esterify the $\mathrm{WCO}$ for biodiesel production in a two-step catalytic process. The first step involved the esterification of the WCO using the acidic ionic liquid catalyst and the second step involved the transesterification of the esterified $\mathrm{WCO}$ by $\mathrm{KOH}$. The highest biodiesel yield was obtained with a $5 \mathrm{wt} \% \mathrm{BMIMHSO}_{4}$, a methanol: oil ratio of $15: 1,60 \mathrm{~min}, 160{ }^{\circ} \mathrm{C}$ and a $600 \mathrm{rpm}$ agitation speed. The IL catalyst reduced the WCO AV to lower than $1.0 \mathrm{mg}$ $\mathrm{KOH} / \mathrm{g}$ [58]. The second step employed a $\mathrm{KOH}$ catalyst $(1.0 \mathrm{wt} \%)$ at $60{ }^{\circ} \mathrm{C}$ and $60 \mathrm{~min}$ and produced a $95.65 \%$ biodiesel yield [58]. In another study, 3-(N,N-dimethyldocecyl ammonium) propane sulfonic acid p-toluene sulfonate ([DDPA] [Tos]) was used as an acid IL catalyst for biodiesel production from soybean oil in the presence of methanol. A biodiesel conversion of over $75 \%$ was obtained when the catalyst amount was $8 \% w / v$, the methanol: oil ratio was $1: 2 \mathrm{v} / \mathrm{v}$, and the reaction temperature was $65^{\circ} \mathrm{C}$ with a $4 \mathrm{~h}$ reaction time and an agitation speed of $300 \mathrm{rpm}$ [59].

Basic ILs are rarely used in biodiesel production compared to acidic ILs, as similar to common basic catalysts, most basic ILs also undergo saponification when used for feedstocks with high FFA content [52,59]. Liang et al. (2010) investigated the use of five basic binuclear ILs containing imidazolium for biodiesel preparation from used cottonseed oil [60]. The highest biodiesel yield was obtained for bis-(3-methyl-1-imidazolium-)ethylene dihydroxide with fractions and selectivity of $98.5 \%$ and $99.99 \%$ at $55{ }^{\circ} \mathrm{C}$ for $4 \mathrm{~h}$ [60], respectively.

The application of ILs in biodiesel production has limitations such as an excess water consumption, the catalyst separation costs and high viscosity [53]. This has resulted in the development of various strategies such as mechanical agitation (ultrasonic and microwave), which shorten the reaction time and save energy $[53,54]$ to improve the efficiency of ILs. Ding et al. (2018) used three acidic imidazolium ionic liquids for the production of biodiesel from palm oil under microwave irradiation. Among the three catalysts, $\left[\mathrm{HSO}_{3}-\mathrm{BMIM}\right] \mathrm{HSO}_{4}$ was the most efficient with a maximum yield of $98.93 \%$ obtained when the methanol: oil ratio, ionic liquid dosage, microwave power and reaction time were $11: 1,9.17 \%, 168 \mathrm{~W}$ and $6.43 \mathrm{~h}$, respectively [61]. In another study, boehmite nanoparticles (BNPs-CCH) stabilized on chlorocholine hydroxide $(\mathrm{CCH})$ were used in the production of biodiesel from soybean oil in the presence of methanol. The maximum yield obtained at the optimum conditions of 11:1 methanol: oil ratio, $4.13 \mathrm{wt} \%$ catalyst weight percent, $60^{\circ} \mathrm{C}$ temperatures and a $4.4 \mathrm{~h}$ reaction time was $95.2 \%$. Furthermore, the catalyst remained efficient after being applied five times under optimum conditions [53].

\subsubsection{Biocatalysts}

The use of enzymes as biocatalysts for the synthesis of biodiesel has recently gained interest since enzyme transesterification has numerous benefits such as mild reaction conditions, low energy consumption, lower reaction temperatures, the complete conversion 
of FFAs to methyl/ethyl esters, a high catalytic efficiency, high selectivity, easy product recovery and the production of high purity biodiesel [62-64]. Lipases are the most widely used enzymes for biodiesel production $[65,66]$. They are versatile catalysts and can be used in solvent-free systems with different co-solvents like organic solvents, ionic liquids or supercritical fluids [66,67].

However, enzymatic catalysis is limited to slower reaction rates compared to the alkaline catalysts, has a high cost compared to chemical catalysis, and the risk of enzyme inhibition and inactivation by alcohols used as substrates (mainly ethanol) and glycerol produced in the reaction is high $[65,66,68]$. Various strategies have been used to deal with these obstacles including enzyme immobilization through a support. Enzyme immobilization provides several advantages including enzyme re-usability, higher reaction rates, better thermal stability, easy separation of products from the enzyme, and a decrease in the inhibition rate resulting in a reduced cost of the catalyst [64,69].

Different immobilization supports such as activated carbon, alginate, chitosan, graphene oxide, magnetite nanoparticle, silica gel, resins, zeolites, etc., have been used [70-73]. Lee et al. (2019) utilized activated carbon oxide (ACO) for the co-immobilization of two different lipases (R. oryzae and C. rugosa) for the production of biodiesel. This resulted in a lipase activity being maintained at about $80 \%$ after 20 times of reuse in a batch system [72]. In another study, the enzyme lipase of Pseudomonas fluorescens immobilized on sodium-modified-SBA-15 was employed as a biocatalyst for the production of biodiesel from different feedstocks in the presence of ethanol. The biocatalyst was able to produce biodiesel from residual or undervalued oils without any pre-treatment [73].

\subsubsection{Heterogeneous Catalysts}

The use of heterogeneous catalysts has received great attention in the production of biodiesel through the esterification method since, unlike other catalysis methods, heterogeneous catalysts improve transesterification by eliminating extra processing costs and by the regeneration of waste [32,74]. Heterogeneous catalysts have advantages such as non-toxicity, low corrosion, the promotion of easy recovery and reusability of the catalyst, they have high stability at elevated temperatures, and they also improve the purity of the yielded biodiesel [32,74-77]. Several synthetic and natural materials that have been investigated as effective heterogeneous catalysts for the transesterification reaction include transition metal oxides, mixed metal oxides, solid catalysts derived from biomass, alkali earth metal oxides, supported, solid acids catalysts-based, and alkali metal compounds supported on alumina or zeolite [34,76,77].

Heterogeneous catalysts are also divided into two subgroups, i.e., solid acid catalysts and solid basic catalysts [77]. The most commonly used solid acid catalysts are inorganic oxide catalysts (zeolites and niobic acids) and ion-exchange resins (Amberlyst-15, Nafion-NR50, Lewatit K2621, K2620, 20BD, 35, Dowex M 31, Tulsion T-42, and Indion 130) $[32,33,78]$. Alkaline metals carbonates $\left(\mathrm{Na}_{2} \mathrm{CO}_{3}, \mathrm{~K}_{2} \mathrm{CO}_{3}\right)$, alkaline earth metal carbonates $\left(\mathrm{CaCO}_{3}\right)$, alkaline earth metal oxides $(\mathrm{CaO}, \mathrm{MgO}, \mathrm{SrO}, \mathrm{BaO})$ and other oxides such as $\mathrm{ZnO}$ are the most studied solid basic catalysts [43]. Recently, waste biomass derived heterogeneous catalysts have gained interest in biodiesel production due to several advantages including being renewable resources, their biodegradability, non-toxicity, reusability, high catalytic activity, stability in both acidic and basic conditions, and their potential to aid in production costs reduction $[34,79,80]$. Coal fly ash (CFA) waste, red mud, slags and tailings, and geothermal waste are some of the intensely researched biomass waste materials with the potential to be re-utilized as heterogeneous catalysts [81-83]. Waste biomass-derived catalysts for biodiesel production are also divided into two sub-groups: heterogeneous base and acid catalysts [79].

CFA is an abundant waste generated during the combustion of coal in thermal power plants [84]. In South Africa, over 30 million tons of CFA is produced annually, with over 800 million tons produced globally $[85,86]$. CFA is composed of heavy metals, silica, polycyclic hydrocarbons, and other toxic substances. These toxic materials have environmental 
risks associated with wet storage in settling ponds and landfills, thus, proper disposal methods are required $[87,88]$. CFA is applied in the construction industry as an additive to cement and concrete manufacturing, in agriculture during soil amelioration and as fill material for low lying areas [89]. In recent years, research has been focused on transforming CFA to high value-added products such as a heterogeneous catalyst to produce valueadded chemicals and an adsorbent for phosphates, dyes and heavy metal ions $[84,86,90]$. In catalysis, CFA has been used as a catalyst support, fly ash derived zeolites, and a solid catalyst $[86,91,92]$.

\subsubsection{Carbon Based Catalysts}

Carbon-based materials such as activated carbon (AC) and carbon nanotubes (CNTs) have found applications as catalyst materials for the production of biodiesel from various feedstocks including waste, crude, refined and pre-treated oils [81,93-95]. Carbon-based catalysts (CBCs) are reusable, cheap, exhibit high surface area and high surface stability, and a uniform distribution of the active particles onto the surface is achieved [31]. CBCs can be applied as acid and alkaline catalysts $[92,96]$. They do not require extensive washing steps, have a simplified overall process, reduce biodiesel production costs while maintaining quality, and they can also be reused in several cycles [35]. Carbon-based alkaline catalysts have been reported to exhibit an improved surface area, have good catalytic efficiency, and can be used on feedstocks with a high FFA content [93,97].

$\mathrm{AC}$ has been applied in several processes involving heterogeneous catalysis. This is attributed to the unique properties such as excellent support properties, inertness, robustness, modifiable surface area, a high number of pores where metal particles can be echoed, and the ability to be synthesized in different sizes and shapes [81,98]. AC is mainly synthesized from high carbon feedstock such as coal, wood, and coconut shell [81]. This material can be prepared using either a physical or chemical activation. Physical activation uses direct gasification of the feedstock, while chemical activation employs agents such as $\mathrm{KOH}, \mathrm{NaOH}, \mathrm{H}_{2} \mathrm{SO}_{4}, \mathrm{H}_{3} \mathrm{PO}_{4}$, and $\mathrm{ZnCl}_{2}$. Both synthesis methods involve thermal cracking [93]. Several studies have been conducted on the use of AC-based heterogeneous catalyst in biodiesel production. In a recent study by Ayoob et al. (2020), waste tires-derived activated carbon (WTAC) was utilised to form a novel carbon base catalyst (KOH/WTAC) for the transesterification reaction of a mixture of non-edible oils with methanol and mixed methanol/ethanol. This process achieved a biodiesel yield of over 93\% [93]. Narowska et al. (2019) used a heterogeneous $\mathrm{KOH} / \mathrm{AC}$ catalyst for the production of biodiesel from waste corn oil in methanol and a $92 \%$ yield was obtained [99]. In another study, a sulfonated heterogeneous catalyst derived from corncob AC was used during a microwave-assisted transesterification of soybean oil in ethanol and a $88.7 \%$ yield of pure phase biodiesel was obtained at optimum conditions [100].

CNTs have been applied in heterogeneous catalysis due to their well-defined structure and desirable properties such as a high surface area, chemical stability, low toxicity, hollow geometry, and easily functionalized surfaces [94,101]. Recently, more research has been focused on the use of sulfonated CNTs as a promising carbon-based solid acid catalyst because of their stability, considerable solubility, the hydrophobic property of the carbon surface that retards unfavourable reactions caused by the presence of water, and sufficient protonic sites [101,102]. Sulfonated CNTs have been prepared in two ways: (i) the growth of CNTs on a stainless-steel substrate to obtain a monolithic carbonaceous catalyst with acid sites, and (ii) the subjection of CNTs to harsh acid treatments with sulphuric acid, introducing $\mathrm{SO}_{3} \mathrm{H}$ on the $\mathrm{CNT}$ surface to produce CNT-SO${ }_{3} \mathrm{H}[102,103]$. Guan et al. (2017) utilized sulfonated multiwalled carbon nanotubes (S-MWCNTs) as a solid acid catalyst for the transesterification reaction of trilaurin with ethanol and a $97.8 \%$ biodiesel yield was obtained [101]. In another study, sulfonated carbon-based nanostructures (CNTs-SO $\left.{ }_{3} \mathrm{H}\right)$ were used for the transesterification of soybean oil in a catalytic distillation column and a $98 \%$ biodiesel yield was obtained at optimum conditions [102]. 


\subsection{Characterization of Biodiesel}

The quality of biodiesel produced is determined by analysing the fuel characteristics. These characteristics are determined by employing methods set out in the ASTM D 6751 and the EN 14214, which are considered as international biodiesel standards (IBS), and being compared to the specifications of these standards [104]. The specifications as per ASTM D 6751 and EN 14214 standards are given in Table 1.

Table 1. ASTM D 6751 and EN 14214 specifications for biodiesel [105,106].

\begin{tabular}{|c|c|c|c|c|}
\hline \multirow{2}{*}{$\begin{array}{c}\text { Properties } \\
\text { Density @ } 15^{\circ} \mathrm{C}\end{array}$} & \multicolumn{2}{|c|}{$\begin{array}{l}\text { ASTM D } 6751 \\
\text { Limit } \\
\text { Method }\end{array}$} & \multicolumn{2}{|c|}{$\begin{array}{l}\text { EN } 14214 \\
\text { Limit } \\
\text { Method }\end{array}$} \\
\hline & $870-890 \mathrm{~kg} / \mathrm{m}^{3}$ & ASTM D4052-91 & $860-900 \mathrm{~kg} / \mathrm{m}^{3}$ & EN ISO 3675, EN ISO 12185 \\
\hline Viscosity @ $40^{\circ} \mathrm{C}$ & $1.9-6.0 \mathrm{~mm}^{2} / \mathrm{s}$ & ASTM D445 & $3.5-5.0 \mathrm{~mm}^{2} / \mathrm{s}$ & EN ISO 3140 \\
\hline $\begin{array}{l}\text { Water content } \\
\text { and sediment }\end{array}$ & $0.050(\% \mathrm{v}) \max$ & ASTM D2709 & $500 \mathrm{mg} / \mathrm{kg}(\max )$ & EN ISO 12937 \\
\hline Flash point & $130^{\circ} \mathrm{C}(\mathrm{min})$ & ASTM D93 & $>101{ }^{\circ} \mathrm{C}(\mathrm{min})$ & EN ISO 3679 \\
\hline Cloud point & Report to customer & ASTM D2500 & $\begin{array}{l}\text { Based on national } \\
\text { specification }\end{array}$ & EN ISO 23015 \\
\hline Calorific value & $35 \mathrm{MJ} / \mathrm{kg}$ & ASTM D240 & & \\
\hline Cetane number & 47 (min) & ASTM D613 & $51(\min )$ & EN ISO 5165 \\
\hline Acid value & $0.50 \mathrm{mg} \mathrm{KOH} / \mathrm{g}(\max )$ & ASTM D664 & $0.50 \mathrm{mg} \mathrm{KOH} / \mathrm{g}(\max )$ & EN 14104 \\
\hline Iodine value & & & $120 \mathrm{~g} / 100 \mathrm{~g}(\max )$ & EN 14111 \\
\hline Total glycerol & $0.24 \% \mathrm{~m} / \mathrm{m}(\max )$ & ASTM D6548 & $0.25 \% \mathrm{~m} / \mathrm{m}$ & EN 14105 \\
\hline Methanol content & & & $0.20 \% \mathrm{~m} / \mathrm{m}(\max )$ & EN 14110 \\
\hline Carbon residue & $0.05 \max w t \%$ & ASTM D4530 & $0.30 \% \mathrm{~m} / \mathrm{m}(\max )$ & EN ISO 10370 \\
\hline Sulphated ash content & $0.020 \% \mathrm{~m} / \mathrm{m}(\max )$ & ASTM D874 & $0.02 \% \mathrm{~m} / \mathrm{m}(\max )$ & EN ISO 3987 \\
\hline
\end{tabular}

Fuel injection is based on a volume metering system; therefore, the density of the biodiesel is very important [107]. Density is the weight per unit volume of a liquid at a particular temperature $[17,104,107]$, while another important characteristic property of biodiesel is viscosity. Viscosity is described as the resistance of an oil to flow smoothly. The higher the viscosity of a liquid, the more difficult it is to flow. Biodiesel with a low viscosity can be easily pumped, atomized and can easily form finer droplets [107]; therefore, determining the water content in biodiesel is also crucial because the water can react with the glycerides to form soap and glycerol, it can corrode the engine and even serve as a media for bacterial growth that can block the filter.

The lowest temperature at which the biodiesel can momentarily ignite in air is known as the flashpoint [108]. A higher flashpoint is favoured to limit the chances of an unexpected fire hazard and auto ignition at high temperatures. The properties that determine the application of biodiesel in cold environmental conditions are the cloud point and the pour point $[28,108]$. The cloud point is usually characterized in biodiesel. It is described as the temperature at which a cloud of crystal first starts to form [107]. The calorific value (CV) of biodiesel is another important characteristic as it indicates the energy content of the biodiesel and consequently its expected consumption [107].

The cetane number $(\mathrm{CN})$ measures the readiness of the biodiesel to ignite after being injected into the combustion chamber [17]. CN is known to increase with an increase in the amount of saturated fatty acids. The $\mathrm{CN}$ should be sufficiently high enough to have a good ignition quality. The AV should also be determined for quality control and monitoring of the degradation of biodiesel during storage $[17,107]$. The iodine value (IV) measures the amount of iodine in grams that can be absorbed by $100 \mathrm{~g}$ of biodiesel and gives the 
unsaturation degree of the biodiesel [20]. This property usually depends on the origin of the feedstock and has an influence on the oxidative tendency of the biodiesel. A number of reactions occur during the frying of oil, such as auto-oxidation, thermal polymerization and hydrolysis that increase the IV.

A high content of free glycerol in biodiesel can settle in storage tanks and create a viscous mixture that could possible block the plug fuel filters and cause engine combustion problems. Methanol content should also be determined as even the smallest amount can decrease the flashpoint of the biodiesel. Obtaining the fatty acid content of the biodiesel helps in determining the amount and type of fatty acids present which, in turn, can help in understanding the viscosity and cold flow properties.

The carbon residue and sulphated ash contents need to be very low in the produced biodiesel. Carbon residue measures the biodiesel's tendency to form carbonaceous material deposits in the engine which can block the nozzle, corrode the engine and even lead to cracking of the fuel component [20]. A high sulphur content can produce sulphur oxides that cause corrosion to the engine and environmental pollution when released into the atmosphere [20].

\subsection{Summary of Important Parameters for the Best Biodiesel Yields}

There are a few parameters that affect the transesterification reaction during biodiesel production and these parameters are able to influence the yield as well as the purity of the biodiesel:

- water and FFA content,

A low moisture and FFA content in the oil favours a high biodiesel yield [15,16],

- $\quad$ alcohol to oil ratio.

As previously mentioned, a 3:1 alcohol to oil molar ratio is needed for the transesterification of oil into biodiesel; however, an excess of alcohol is required to ensure that the contact between the alcohol and triglyceride is maximized in order to minimize any possibility of the reaction reversing [28]. An excess of alcohol also promotes the breaking of the glycerine-FA linkages thus producing higher conversion rates and an increase in the yield purity. On the other hand, if the alcohol is too much, it could negatively impact the yield and complicate the glycerol separation process. A continuous increase in the concentration of glycerol and alkyl ester increases the chances of recombination into monoglycerides thus decreasing the biodiesel yield. A study that investigated different methanol to oil ratios from 4:1 to 10:1 revealed that the highest yield (96\%) was obtained at a ratio of 8:1 [109].

- Reaction temperature

Higher reaction temperatures encourage the conversion of oil into biodiesel thus enabling the yield to increase in a shorter reaction time [29]. The viscosity of the oil decreases with an increase in temperature. This allows the oil and alcohol to mix faster leading to a rapid glycerol and biodiesel separation. When the reaction temperatures are too high, the side reactions occur faster than the main transesterification reaction thus producing a lower biodiesel yield [27]. Studies have shown that the optimal temperature for transesterification is $50-70{ }^{\circ} \mathrm{C}$ [110].

\section{- Reaction time}

A longer reaction time can ensure that the reaction reaches completion. A maximum yield of biodiesel can be obtained in less than $90 \mathrm{~min}$; however, if the reaction is extended for too long, the yield decreases as reverse transesterification and saponification takes place [111].

- Catalyst concentration

A catalyst enhances the biodiesel conversion rate thus increasing the yield [29]. The catalyst loading is related to the waste oil and type of catalyst. The optimum catalyst loading of $\mathrm{NaOH}, \mathrm{KOH}$ and $\mathrm{CH}_{3} \mathrm{Na}$ have been reported as $1.1 \%, 1.5 \%$ and $1.3 \%$, respectively [5].

- Purification 
Biodiesel produced post-transesterification is usually subjected to a purification step immediately after product settling and glycerol removal. This is to remove residuary such as $\mathrm{KOH} / \mathrm{NaOH}$, glycerol remains, methanol/ethanol, moisture and leftover glycerides in order to improve the quality of the product [112]. This is normally completed through hot-water wash cycles followed by a drying step [112,113].

\section{Technical and Economic Feasibility Overview}

\subsection{Biodiesel Plant Considerations}

When looking into the economic cycle of biodiesel production, one of the most important factors to consider is the infrastructure requirements for its production facilities. The transesterification reactor, decanter, distillation, utility costs, labour, maintenance and other running costs should all be considered. The factors influencing the transesterification reaction discussed earlier (including the type of catalyst, reaction time, alcohol, oil composition and temperature) as well as the production scale, all play a significant role in the cost requirements for the biodiesel plant [114]. WCO varies in composition depending on the oil source, heating time and temperature, and the number of times the oil was repeatedly used by the supplier. To establish relevant areas for biodiesel plants across SA, it is necessary to determine all the logistics costs related to the collection of WCO from various supply sources for a complete economic evaluation [112,114]. The 1.22 million $\mathrm{km}^{2}$ area of SA land is divided into nine provinces with high varying population densities as shown in Table 2.

Table 2. South Africa's latest population estimates as of July 2021 [115].

\begin{tabular}{ccccc}
\hline Province & Population & $\%$ & $\begin{array}{c}\text { Square } \\
\text { Kilometres }\end{array}$ & $\begin{array}{c}\text { 2017 SA Economy } \\
\text { Contribution by } \\
\text { Province [116] } \\
\text { (\%) }\end{array}$ \\
\hline Gauteng & $15,810,338$ & 26.3 & 18,178 & 34 \\
\hline KwaZulu-Natal & $11,513,575$ & 19.1 & 94,361 & 16 \\
\hline Western Cape & $7,113,776$ & 11.8 & 129,462 & 14 \\
\hline Eastern Cape & $6,676,590$ & 11.1 & 168,966 & 8 \\
\hline Limpopo & $5,926,724$ & 9.8 & 125,755 & 8 \\
\hline Mpumalanga & $4,743,584$ & 7.9 & 76,495 & 6 \\
\hline North West & $4,122,854$ & 6.9 & 104,882 & 5 \\
\hline Free State & $2,932,441$ & 4.9 & 129,825 & 2 \\
\hline Northern Cape & $1,303,047$ & 2.2 & 372,889 & Total: $1,220,813$ \\
\hline
\end{tabular}

Gauteng is the densest area and highest contributor to the country's economy followed by KwaZulu-Natal and the Western Cape, respectively. These provinces also contain a much higher number of hotels and restaurants, when compared to other provinces, in line with their high economic activities and population. It would therefore be necessary to consider each of these provinces separately based on their geographical outlines and population of the potential consumers per plant, which will determine the transportation requirements of WCO and biodiesel as well as the plant size, respectively. Determination of the profitability of each production facility requires high accuracy in order to project the size of investments required for a sustainable operation as well as provide data for start-up companies. Sales revenues from the biodiesel production by-product also contribute to the overall economic evaluation of the process. Currently, these three top provinces, together with the Eastern Cape, are the four provinces that have commercial producers of biodiesel in SA. This biodiesel is used to run heavy machinery as a replacement to fossil diesel or as a blend to improve fossil diesel properties, albeit only at a small scale. 
A study conducted by Iglesias et al. (2012) compared centralised and decentralized sunflower oil and WCO-based biodiesel production systems in Spain [9]. They reported that a degree of decentralisation would contribute to a cleaner environment if transportation of the WCO was minimised [9]. The overall study showed that each territory required special considerations before a centralised or decentralised production systems could be established.

In a recent review by Tabatabaei et al. (2019), it was discovered that among the various available biodiesel reactors, none were perfect as each one had both pros and cons, and process intensification techniques were being employed in order to improve the economic profitability of the processes [114]. Fawaz and Salam (2018) reported on a preliminary economic assessment of using waste frying oil (WFO) to produce biodiesel in Lebanon, comparing a lab-scale reactor and a biodiesel plant to determine the cost of production [117]. They also collected data from 100 restaurants and hotels in Beirut in order to evaluate the generation of WFOs and their potential contribution to the biodiesel supply chain, and further proposed a vehicle routing model scenario for a profitable waste oil collection logistics network [117]. After assessment, they reported that biodiesel production was economically competitive with fossil diesel when a subsidy policy on waste frying oils acquisition costs was implemented by the government and that biodiesel production offered better environmental benefits and a net energy gain [117].

Another study by Farid et al. (2020) investigated the net energy and techno-economic assessment of biodiesel production from WCO using a semi-industrial plant (100 litre capacity) with the intention of using the acquired data to develop a detailed economic outline and profitability analysis for a full-scale (15 tonnes per batch per day with 330 production cycles per annum) production plant projection [112]. They reported that their proposed system would be quite profitable offering strong business growth for 10 years while a sensitivity analysis showed a vulnerability to changes in WCO prices and plant capacity [112]. Araujo et al. (2010) reported on the economic viability of biodiesel production in a Brazil-based urban centre and the relevance of logistics in the overall production costs [118]. This study investigated the logistics involved when using WFO as a biodiesel feedstock and a mathematical programming model was proposed to solve the vehicle routing challenges in Rio de Janeiro, Brazil. An optimized logistic cost of USD 0.11 per litre using a mediumduty commercial vehicle represented approximately $15 \%$ of the overall expenditures for biodiesel production. The significance of their findings emphasized the importance of logistics with regards to a complete economic assessment examination of biodiesel production from WFO [118].

\subsection{Biofuels Industry, $S A$}

Internationally, biofuels industry growth has been driven by several factors which include:

- $\quad$ investments towards renewable energy and environmentally friendly energy sources to reduce global warming,

- empowering the agricultural sector,

- $\quad$ promotion of sustainable development, exertion of downward pressure on global crude oil prices and the need to improve energy security.

The South African Biofuels Industrial Strategy (2006) outlines the biofuels programme as a strategy to uplift agricultural sectors and to unlock substantial economic benefits in sub-Saharan Africa by, inter alia, attracting investment and promoting agricultural development [119].

The Cleaner Fuels Programme is accountable for the gradual removal of leaded petrol and sulphur reduction in diesel to a maximum of $0.05 \%$ (mass) in 2006. Guidelines bulletined in June 2006 under the Petroleum Products Amendment Act comprised a specific allowance for biodiesel addition and mandates fuel specifications according to the South African National Standards (SANS) [119]. These specifications are in line with EN, ASTM and Japanese standards. 
The National Biofuels Industrial Strategy seeks to encourage rural development and reduce poverty through job creation. An investment through a biofuels plant is envisaged to be a catalyst for transforming rural economies and contributing towards the government's Accelerated and Shared Growth Initiative (AsgiSA). Biofuels are furthermore expected to contribute towards the achievement of the renewable energy goals, energy security and the reduction of greenhouse gas emissions [119].

This strategy proposed an initial biofuels penetration of $2 \%$ of road liquid fuels that will have a producer support scheme and requires the use of local crops grown mainly on currently underutilised land in the former homelands with support from commercial land. This was envisaged to create 25,000 jobs with a capital spend per job reaching less than $65 \%$ of the Industrial Development Corporation target. Success of this program would reduce unemployment by $0.6 \%$ (mainly in rural areas); boost economic growth by $0.05 \%$ (or $2.5 \%$ of the AsgiSA target increase); achieve a balance of payments saving of ZAR 1.7 billion; and achieve a greenhouse gas emissions' saving of ZAR 100 million per annum [119]. This strategy also recommended a blending requirement of $2 \%$ for biodiesel and $8 \%$ for bioethanol.

The South African Biofuels Chair admitted in the 2009 report that progress, especially investment, in the development of the country's biofuels industry had been especially modest. According to the report, several commercial biofuel plants had been established. Only biodiesel was currently being produced for the transport market, and this was from the more than 200 small-scale initiatives that use recycled vegetable oil, most of which were established long before the Strategy was released in 2007 [120].

\subsection{Relevance to the South African Economy and Legislature}

The South African Cabinet approved the National Biofuels Industrial Strategy in December 2007. The regulations for mandatory blending of biofuels with petrol and diesel were promulgated in August 2012 and came into effect in October 2015. The Biofuels Regulatory Framework sketches the strategy of financial support for the emerging biofuels industry and outlines the strategy for project selection and support, and how the projects would be selected and supported. The blending of biofuels reduces the impact of fuel emissions [121].

The Mineral and Petroleum Resources Development Act No. 28 of 2002 (MPRDA), provides for impartial access to and the sustainable development of the nation's mineral and petroleum resources, and it provides for matters connected therewith [122].

The MPRDA recognises that minerals and petroleum are non-renewable natural resources and it seeks to give effect to Section 24 of the Constitution [123] by ensuring that the nation's mineral and petroleum resources are developed in an orderly and ecologically sustainable manner while promoting justifiable social and economic development [123].

The National Energy Act No. 34 of 2008 seeks to ensure that diverse energy resources are available, in sustainable quantities and at affordable prices, to the South African economy in support of economic growth and poverty alleviation, while taking into account the environmental management requirements and interactions amongst economic sectors.

\subsubsection{Selected Legislation Governing Waste in South Africa}

\section{* National Environmental Management: Waste Act No. 59 of 2008}

- $\quad$ The objects of the National Environmental Management Waste Act 59 of 2008 are to protect health, well-being and the environment by providing reasonable measures for avoiding and minimizing the generation of waste; reducing, reusing, recycling and recovering waste; treating and safely disposing of waste as a last resort; promoting and ensuring the effective delivery of waste services; and generally, to give effect to Section 24 of the Constitution in order to secure an environment that is not harmful to health and well-being.

* National Waste Management Regulations, 2012 
- Published in terms of Section 69 of the National Environmental Management: Waste Act No. 59 of 2008 [124]. The purpose of the regulations is to regulate the collection of data and information to fulfil the objectives of the national waste information system as set out in Section 61 of the Waste Act [125].

\subsubsection{Primary Laws and Regulations the Oil and Gas Industry in South Africa}

* The Mineral and Petroleum Resources Development Act (Act No. 28 of 2002) - this is the framework legislation in terms of which upstream oil and gas rights are granted and controlled, together with prospecting and mining rights. The government has indicated that it will seek to separate the regulation of oil and gas from that of mining by enacting a separate legislative framework in the medium term.

* The Petroleum Pipelines Act (Act No. 60 of 2003) — this provides the regulatory framework for the construction and operation of petroleum pipelines, loading facilities and storage facilities.

- The Petroleum Products Act (Act No. 120 of 1977) —-this regulates the downstream sector, establishing the scheme for the licensing of wholesalers, retailers and manufacturers of petroleum products.

- The Gas Act (Act No. 48 of 2001) - this provides the regulatory framework for the construction and operation of gas transmission, storage, distribution, liquefaction and re-gasification facilities, as well as for trading in gas.

* The National Environmental Management Act (Act No. 107 of 1999)—-this was enacted as framework legislation for environmental management in SA. It subjects various activities to environmental authorisation, including oil and gas exploration, production and decommissioning. Since November 2015, the act has also imposed additional environmental obligations, such as the furnishing of financial provision for environmental obligations relating to the rehabilitation and remediation of areas in which exploration and production activities have been conducted.

* The International Trade and Administration Act (Act No. 71 of 2002) - this regulates the import and export of petroleum and petroleum products to SA. A list setting out the commodities that require import and export permits is published by the minister of trade.

4.3.3. Government Bodies Who Are Charged with Regulating the Oil and Gas Industry in South Africa

- Department of Mineral Resources-administers the Mineral and Petroleum Resources Development Act, which is the principal statute governing the exploration for and production of petroleum resources. It is also the competent authority to issue environmental authorisations under the National Environmental Management Act.

- Department of Energy - is the controller of petroleum products within the Department of Energy and is the licensing authority under the Petroleum Products Act.

- Petroleum Agency of South Africa-has been delegated various first-tier functions in terms of the Mineral and Petroleum Resources Development Act relating to the acceptance and consideration of applications for petroleum rights and permits.

- National Energy Regulator of South Africa (NERSA) —administers and is the competent licensing authority under the Petroleum Pipelines Act and the Gas Act.

According to the Department of Energy (DoE), SA, biofuels had a market share of 2.5\% in the energy sector in 2016 [126]. According to the DoE 2017 report, petrol consumption declined between 2007 and 2016 whereas diesel consumption grew at an annual average of 3\% between 2007 and 2015. Both petrol and diesel consumption exceeded the local supply and as a result the demand was met by imports. The DoE report also revealed that approximately $70 \%$ of petrol and diesel was consumed by the transport sector, and a decline in the market share of petrol-fuelled vehicles' sales from 73\% in 2007 to $63 \%$ in 2016 was observed, while an increase in diesel-fuelled vehicles' sales by 10 percentage points was also observed over the same period. The report also noted that diesel is largely used in the 
commercial sector unlike petrol that is dominated by the retail sector, and as a result, diesel consumption largely depends on the country's economic growth [126]. A consumption of $57.3 \%$ of the total consumed diesel was attributed to the Gauteng, KwaZulu-Natal and the Western Cape provinces combined.

One of the enabling milestones under the National Development Plan 2030 - to eliminate income poverty and reduce inequality - is to produce sufficient energy to support industry at competitive prices, ensuring access for poor households, while reducing the carbon emissions per unit of power by about one-third [127]. Biodiesel production from waste oils fits within this plan and appropriate planning and advanced policies should be promulgated to encourage national biodiesel consumption. A recent government notice from the DoE highlights the importance of promoting the use of biofuels with special concerns with regards to available land and rainfall [128].

\section{Conclusions and Prospects}

The use of WCO as a feedstock for biodiesel production is easily the most convenient choice especially when considering the low cost, reduced greenhouse gas emission footprint, fuel vs. food crop land competition, accessibility of feedstock and sustainability. Unlike fossil diesel production, biodiesel production does not require a complicated infrastructure and semi-industrial pilot plants are used in many parts of the world. A current literature review suggests that the production of biodiesel from WCO using the transesterification process yields high quality diesel with properties comparable to fossil diesel and meets the ASTM 6751 and EN 14214 standards. Various economic assessments have been carried out by researchers in countries with large-scale biodiesel production from WCO and the results show many factors that affect the final selling price of biodiesel, which should be considered. The biodiesel economy has been shown to be most sensitive to feedstock prices as well as the plant scale, thus, local vegetable oil production would help in maintaining prices through government interventions.

South Africa's biofuels industry is sitting at only about $2.5 \%$ of the market share of liquid fuels. The country's liquid fuel demands are still being met by imports which make fuel prices quite high. Intensive research that has been carried out in different parts of the world has most commonly reported that the use of vegetable oils for biodiesel production is environmentally friendly but also quite expensive when compared to fossil diesel. The crop farming initiative that was proposed in the SA Biofuels Strategy of 2006 is still very much necessary for vegetable oil production that can be consumed in the food sector rather than biodiesel, especially when vegetable oil consumption results in large quantities of WCO which has been shown to be an effective feedstock for biodiesel production at affordable prices. The strategy is also very relevant for job creation and for minimizing the country's dependence on oil imports. There are a number of items that the SA government, stakeholders and start-up companies could consider in order to promote biodiesel production from WCO:

$>\quad$ The SA government can invest in promoting behavioural change among its residents in order to achieve a better collection of waste oils. This can be achieved by creating WCO collection centres in each municipality and appropriating financial rewards for every litre of WCO collected. This could be especially useful in the rural areas where it is easier for people to deliver WCO when travelling to town for their normal shopping activities than it would be for a waste collection vehicle to travel throughout the different remote municipal regions.

$>$ The hotels, restaurants and fast-food chains that produce large quantities of WCO are usually located in easily accessible areas. A well-managed waste collection system including specified travel routes for each municipality would help minimise transport costs. Further, government tax exemption incentives for companies that store and sell WCO could encourage cooperation in the hospitality industry.

$>\quad$ Policy can phase-out or reduce the manufacturing and sale of petrol consuming machinery in a bid to promote diesel machinery sales, which can also accommodate 
biodiesel and biodiesel blends with fossil diesel. This would also help reduce the emission of greenhouse gases.

$>$ The Government can increase investments towards renewable energy and specifically expand on the expectations for biofuels.

$>$ The Government can promote the design of semi-industrial plants that can be easily accessed by interested entrepreneurs.

South Africa is currently presented with a number of choices to make and its rising interest in biodiesel production should come with many rewards. There is currently a growing interest in the advancement of biodiesel production via the transesterification route for commercial purposes, using environmentally sustainable and economically profitable technologies. There is a gap in the engineering of affordable and scalable transesterification reactors that can effectively accommodate WCO feedstock. WCO feedstock sustainability relates to the growing population and associated demands. Biodiesel production from WCO will potentially reduce the costs associated with petroleum-based oil imports and boost the country's economy.

Author Contributions: Conceptualization E.C.L., S.D. and L.Z.L., writing-original draft preparation, E.C.L., B.T., L.P.M. and S.D., writing-review and editing T.E.M., L.Z.L., N.M. and Z.N.T., formal analysis, E.C.L. and S.D. funding acquisition, E.C.L. All authors have read and agreed to the published version of the manuscript.

Funding: The University of the Witwatersrand and The National Research Foundation (NRF Thuthuka grant number 129532) are acknowledged for their financial support.

Acknowledgments: The National Research Foundation (NRF Thuthuka UID 129532) and The University of the Witwatersrand are acknowledged for financial support. S. Dziike is acknowledged for compiling a list of relevant legislation.

Conflicts of Interest: The authors declare no conflict of interest.

\section{References}

1. South Africa. Available online: https://knoema.com/atlas/South-Africa/topics/Energy/Oil (accessed on 24 January 2022).

2. Yasar, F. Comparison of fuel properties of biodiesel fuels produced from different oils to determine the most suitable feedstock type. Fuel 2020, 264, 1-7. [CrossRef]

3. Knothe, G. Biodiesel and renewable diesel: A comparison. Prog. Energy Combust. Sci. 2010, 36, 364-373. [CrossRef]

4. Wang, T. Global Biodiesel Production by Country 2018. Statista. 2020. Available online: https://www.statista.com/statistics/27 1472/biodiesel-production-in-selected-countries / (accessed on 25 May 2020).

5. Phan, A.N.; Phan, T.M. Biodiesel Production from Waste Cooking Oils. Fuel 2008, 87, 3490-3496. [CrossRef]

6. Zhang, Y.; Dube, M.A.; McLean, D.D.; Kates, M. Biodiesel production from waste cooking oil: 2. Economic assessment and sensitivity analysis. Bioresour. Technol. 2003, 90, 229-240. [CrossRef]

7. National Waste Information Regulations. South Africa. 2012. Available online: https://www.ecolex.org/details/legislation/ national-waste-information-regulations-no-r-625-of-2012-lex-faoc117326/ (accessed on 18 May 2020).

8. Chhetri, A.B.; Watts, K.C.; Islam, M.R. Waste cooking oil as an alternate feedstock for biodiesel production. Energies 2008, 1, 3-18. [CrossRef]

9. Iglesias, L.; Laca, A.; Herrero, M.; Diaz, M. life cycle assessment comparison between centralized and decentralized biodiesel production from raw sunflower oil and waste cooking oils. J. Clean. Prod. 2012, 37, 162-171. [CrossRef]

10. MKulkarni, G.; Dalai, A.K. Waste cooking oils-An economical source for biodiesel: A review. Ind. Eng. Chem. Res. 2006, 45, 2901-2913. [CrossRef]

11. Haas, M.J.; Aloon, A.J.M.; Yee, W.C.; Foglia, T.A. A process model to estimate biodiesel production costs. Bioresour. Technol. 2006, 97, 671-678. [CrossRef]

12. Attari, A.; Abbaszadeh-Mayvan, A.; Taghizadeh-Alisaraei, A. Process optimization of ultrasonic-assisted biodiesel production from waste cooking oil using waste chicken eggshell-derived $\mathrm{CaO}$ as a green heterogeneous catalyst. Biomass Bioenergy 2022, 158, 1-16. [CrossRef]

13. Kirubakaran, M.; Selvan, V.A.M. A comprehensive review of low cost production from waste chicken fat. Renew. Sustain. Energy Rev. 2018, 83, 390-401. [CrossRef]

14. Dimian, A.C.; Kiss, A.A. Eco-efficient processes for biodiesel poduction from waste lipids. J. Clean. Prod. 2019, 239, 1-15. [CrossRef]

15. Yaakob, Z.; Mohammad, M.; Alherbawi, M.; Alam, Z.; Sopian, K. Overview of the production of biodiesel from waste cooking oil. Renew. Sustain. Energy Rev. 2013, 18, 184-193. [CrossRef] 
16. Refaat, A.A. Different techniques for the production of biodiesel from waste vegetable oil. Int. J. Environ. Sci. Technol. 2010, 7, 183-213. [CrossRef]

17. Yasin, M.H.M.; Mamat, R.; Yusop, A.F.; Rahim, R.; Aziz, A.; Shah, L.A. Physical Characteristics of Biodiesel Blend Fuels with Alcohol and Additives. Procedia Eng. 2013, 53, 701-706. [CrossRef]

18. Thoai, D.N.; Hang, P.T.L.; Lan, D.T. Pre-treatment of waste cooking oil with high free fatty acids content for biodiesel production: An optimization study via response surface methodology. Vietnam J. Chem. 2019, 57, 568-573. [CrossRef]

19. Sahar; Sadaf, S.; Iqbal, J.; Ullah, I.; Bhatti, H.N.; Nouren, S.; Habbib-ur-Rehman; Nasir, J.; Iqbal, M. Biodiesel production from waste cooking oil: An efficient technique to convert waste into biodiesel. Sustain. Cities Soc. 2018, 41, 220-226. [CrossRef]

20. Shalaby, E.A.; El-Gendy, N.S. Two steps alkaline transesterification of waste cooking oil and quality assessment of produced biodiesel. Int. J. Chem. Biochem. Sci. 2012, 1, 30-35.

21. Asri, N.P.; Sari, D.A.P.; Poedjojono, B.; Suprapto. Pre-treatment of waste frying oils for biodiesel production. Mod. Appl. Sci. 2015, 9, 99-106. [CrossRef]

22. Ozbay, N.; Oktar, N.; Tapan, N. Esterification of free fatty acids in waste cooking oils (WCO): Role of ion-exchange resins. Fuel 2008, 87, 1789-7898. [CrossRef]

23. Gude, V.G.; Patil, P.; Martinez-Guerra, E.; Deng, S.; Nirmalakhandan, N. Microwave energy potential for biodiesel production. Sustain. Chem. Processes 2013, 1, 1-5. [CrossRef]

24. Singh, D.; Sharma, D.; Soni, S.L.; Sharma, S.; Sharma, P.K.; Jhalani, A. A review on feedstocks, production processes, and yield for different generations of biodiesel. Fuel 2019, 262, 1-15. [CrossRef]

25. Kapilan, N.; Bayko, D.; Baykov, A. Review on new methods used for the production of biodiesel. Pet. Coal 2014, 56, 62-73.

26. Lotero, E.; Liu, Y.; Lopez, D.E.; Suwannkarn, K.; Bruce, D.A.; Goodwin, J.G. Synthesis of biodiesel via acid catalysis. Ind. Eng. Chem. Res. 2005, 44, 5353-5363. [CrossRef]

27. Sivaprakasam, S.; Saravanaan, C.G. Optimization of the transesterification process for biodiesel production and use of biodiesel in a compression ignition engine. Energy Fuels 2007, 21, 2998-3003. [CrossRef]

28. Musa, I.A. The effects of alcohol to molar ratios and the type of alcohol on biodiesel production using transesterification process. Egypt. J. Pet. 2016, 25, 21-31. [CrossRef]

29. Lam, M.K.; Lee, K.T. Mixed methanol-ethanol technology to produce greener biodiesel from waste cooking oil: A breakthrough for $\mathrm{SO}_{4}{ }^{2-} / \mathrm{SnO}_{2}-\mathrm{SiO}_{2}$ catalyst. Fuel Processing Technol. 2011, 92, 1639-1645. [CrossRef]

30. Issariyakul, T.; Kulkarrni, M.G.; Dalai, A.K.; Bakhshi, N.N. Production of biodiesel from waste fryer grease using mixed methanol/ethanol system. Fuel Processing Technol. 2007, 88, 429-436. [CrossRef]

31. Mohadesi, M.; Aghel, B.; Maleki, M.; Ansari, A. Production of biodiesel from waste cooking oil using a homogeneous catalyst: Study of semi-industrial pilot of microreactor. Renew. Energy 2019, 136, 677-682. [CrossRef]

32. Thangaraj, B.; Solomon, P.R.; Muniyandi, B.; Ranganathan, S.; Lin, L. Catalysis in biodiesel production-A review. Clean Energy 2018, 3, 2-23. [CrossRef]

33. Di Bitonto, L.; Pastore, C. Metal hydrated-salts as efficient and reusable catalysts for pre-treating waste cooking oils and animal fats for an effective production of biodiesel. Renew. Energy 2019, 143, 1193-1200. [CrossRef]

34. Chua, S.Y.; Periasamy, L.A.; Goh, C.M.H.; Tan, Y.H.; Mubarak, N.M.; Kansedo, J.; Khalid, M.; Walvekar, R.; Abdullah, E.C. Biodiesel synthesis using natural solid catalyst derived from biomass waste-A review. J. Ind. Eng. Chem. 2020, 81, 41-60. [CrossRef]

35. Selvaraj, R.; Praveenkumar, R.; Moorthy, I. A comprehensive review of biodiesel production methods from various feedstocks. Biofuels 2016, 10, 325-333. [CrossRef]

36. Celante, D.; Schenkel, J.V.D.; de Castilhos, F. Biodiesel production from soybean oil and dimethyl carbonate catalyzed by potassium methoxide. Fuel 2018, 212, 101-107. [CrossRef]

37. Bashir, M.J.K.; Wong, L.P.; Hilaire, D.S.; Kim, J.; Salako, O.; Jean, M.J.; Adeyemi, R.; James, S.; Foster, T.; Pratt, L.M. Biodiesel fuel production from brown grease produced by wastewater treatment plant: Optimization of acid catalyzed reaction conditions. J. Environ. Chem. Eng. 2020, 8, 1-8. [CrossRef]

38. Thushari, I.; Babel, S.; Samart, C. Biodiesel production in an autoclave reactor using waste palm oil and coconut coir husk derived catalyst. Renew. Energy 2019, 134, 125-134. [CrossRef]

39. AbdelDayem, H.M.; Sabil, B.G.; El-Hosiny, F.I. Facile synthesis of hydrothermal stable hierarchically macro-mesoporous hollow microspheres $\gamma-\mathrm{Al}_{2} \mathrm{O}_{3}$-graphene oxide composite: As a new efficient acid-base catalyst for transesterification reaction for biodiesel production. Fuel 2020, 277, 1-10. [CrossRef]

40. Nath, B.; Das, B.; Kalita, P.; Basumatary, S. Waste to value addition: Utilization of waste Brassica nigra plant derived novel green heterogeneous base catalyst for effective synthesis of biodiesel. J. Clean. Prod. 2019, 239, 1-15. [CrossRef]

41. Ramadhas, A.S.; Jayaraj, S.; Muraleedharan, C. Biodiesel production from high FFA rubber seed oil. Fuel 2005, 84, 335-340. [CrossRef]

42. Mohadesi, M.; Aghel, B.; Maleki, M.; Ansari, A. The use of $\mathrm{KOH} /$ Clinoptilolite catalyst in pilot of microreactor for biodiesel production from waste cooking oil. Fuel 2020, 263, 1-10. [CrossRef]

43. Ferreira, R.S.B.; dos Passos, R.M.; Sampaio, K.A.; Batista, E.A.C. Heterogeneous catalysts for biodiesel production: A review. Food Public Health 2019, 9, 125-137. [CrossRef] 
44. Romero, R.; Martinez, S.L.; Nativi, R. Biodiesel production by using heterogeneous catalysts. In Alternative Fuel; IntechOpen: London, UK, 2011. [CrossRef]

45. Kamran, E.; Mashhadi, H.; Mohammadi, A.; Ghobadian, B. Biodiesel production from Elaeagnus angustifolia L. seed as a novel waste feedstock using potassium hydroxide catalyst. Biocatal. Agric. Biotechnol. 2020, 25, 1-7. [CrossRef]

46. Vadery, V.; Cherikkallinmel, S.K.; Ramakrishnan, R.M.; Sugunan, S.; Narayanan, B.N. Green production of biodiesel over waste borosilicate glass derived catalyst and the process up-gradation in pilot scale. Renew. Energy 2019, 141, 1042-1053. [CrossRef]

47. Thirugnanasambandham, K.; Shine, K.; Agatheeshwaren, A.; Sivakumar, V. Biodiesel production from castor oil using potassium hydroxide as a catalyst: Simulation and validation. Energy Sources Part A Recovery Util. Environ. Eff. 2016, 38, $2898-2905$. [CrossRef]

48. Pisitpong, I.; Sotsanan, L.; Luengnaruemitchai, A.; Samai, J.I. Biodiesel production from palm oil using potassium hydroxide loaded on ZrO2 catalyst in a batch reactor. Chiang Mai J. Sci. 2014, 41, 128-137.

49. Sukasem, N.; Manophan, S. The development of biodiesel production from vegetable oils by using different proportions of lime catalyst and sodium hydroxide. Energy Procedia 2017, 138, 991-997. [CrossRef]

50. Baroutian, S.; Aroua, M.K.; Raman, A.A.A.; Sulaiman, N.M.N. Potassium hydroxide catalyst supported on palm shell activated carbon for transesterification of palm oil. Fuel Processing Technol. 2010, 91, 1378-1385. [CrossRef]

51. Troter, D.Z.; Todorović, Z.B.; Đokić-Stojanović, D.R.; Stamenković, O.S.; Veljković, V.B. Application of ionic liquids and deep eutectic solvents in biodiesel production: A review. Renew. Sustain. Energy Rev. 2016, 61, 473-500. [CrossRef]

52. Liu, C.Z.; Wang, F.; Stiles, A.R.; Guo, C. Ionic liquids for biofuel production: Opportunities and challenges. Appl. Energy 2012, 92, 406-414. [CrossRef]

53. Hosseini, S.; Moradi, G.R.; Bahrami, K. Synthesis of a novel stabilized basic ionic liquid through immobilization on boehmite nanoparticles: A robust nanocatalyst for biodiesel production from soybean oil. Renew. Energy 2019, 138, 70-78. [CrossRef]

54. Yan, J.; Zhao, Y.; Li, K.; Zhang, H.; Fan, L.; Lu, Z. Efficient production of biodiesel from ionic liquid catalyzed esterification using ultrasonic-microwave combined intensification. Chem. Eng. Processing-Process. Intensif. 2020, 149, 1-9. [CrossRef]

55. Ullah, Z.; Khan, A.S.; Muhammad, N.; Ullah, R.; Alqahtani, A.S.; Shah, S.N.; Ghanem, O.B.; Bustam, M.A.; Man, Z. A review on ionic liquids as perspective catalysts in transesterification of different feedstock oil into biodiesel. J. Mol. Liq. 2018, 266, 673-686. [CrossRef]

56. Wahidin, S.; Idris, A.; Yusof, N.M.; Kamis, N.H.H.; Shaleh, S.R.M. Optimization of the ionic liquid-microwave assisted one-step biodiesel production process from wet microalgal biomass. Energy Convers. Manag. 2018, 171, 1397-1404. [CrossRef]

57. Roman, F.F.; Ribeiro, A.E.; Queiroz, A.; Lenzi, G.G.; Chaves, E.S.; Brito, P. Optimization and kinetic study of biodiesel production through esterification of oleic acid applying ionic liquids as catalysts. Fuel 2019, 239, 1231-1239. [CrossRef]

58. Ullah, Z.; Bustam, M.A.; Man, Z. Biodiesel production from waste cooking oil by acidic ionic liquid as a catalyst. Renew. Energy 2015, 77, 521-526. [CrossRef]

59. Panchal, B.; Chang, T.; Qin, S.; Sun, Y.; Wang, J.; Bian, K. Optimization of soybean oil transesterification using an ionic liquid and methanol for biodiesel synthesis. Energy Rep. 2019; in press. [CrossRef]

60. Liang, J.H.; Ren, X.Q.; Wang, J.T.; Jinag, M.; Li, Z.J. Preparation of biodiesel by transesterification from cottonseed oil using the basic dication ionic liquids as catalysts. J. Fuel Chem. Technol. 2010, 38, 275-280. [CrossRef]

61. Ding, H.; Ye, W.; Wang, Y.; Wang, X.; Li, L.; Liu, D.; Gui, J.; Song, C.; Ji, N. Process intensification of transesterification for biodiesel production from palm oil: Microwave irradiation on transesterification reaction catalyzed by acidic imidazolium ionic liquids. Energy 2018, 144, 957-967. [CrossRef]

62. Gong, H.; Gao, L.; Nie, K.; Wang, M.; Tan, T. A new reactor for enzymatic synthesis of biodiesel from waste cooking oil: A static-mixed reactor pilot study. Renew. Energy 2020, 154, 270-277. [CrossRef]

63. Saranya, G.; Ramachandra, T.V. Novel biocatalyst for optimal biodiesel production from diatoms. Renew. Energy 2020, 153, 919-934. [CrossRef]

64. Ashjari, M.; Garmroodi, M.; Asl, F.A.; Emampour, M.; Yousefi, M.; Lish, M.P.; Habibi, Z.; Mohammadi, M. Application of multicomponent reaction for covalent immobilization of two lipases on aldehyde-functionalized magnetic nanoparticles; Production of biodiesel from waste cooking oil. Process. Biochem. 2020, 90, 156-167. [CrossRef]

65. Badoei-dalfard, A.; Malekabadi, S.; Karami, Z.; Sargazi, G. Magnetic cross-linked enzyme aggregates of Km12 lipase: A stable nanobiocatalyst for biodiesel synthesis from waste cooking oil. Renew. Energy 2019, 141, 874-882. [CrossRef]

66. Ching-Velasquez, J.; Fernández-Lafuente, R.; Rodrigues, R.C.; Plata, V.; Rosales-Quintero, A.; Torrestiana-Sánchez, B.; TaciasPascacio, V.G. Production and characterization of biodiesel from oil of fish waste by enzymatic catalysis. Renew. Energy 2020, 153, 1346-1354. [CrossRef]

67. Tacias-Pascacio, V.G.; Torrestiana-Sánchez, B.; Magro, L.D.; Virgen-Ortíz, J.J.; Suárez-Ruíz, F.J.; Rodrigues, R.C.; FernandezLafuente, R. Comparison of acid, basic and enzymatic catalysis on the production of biodiesel after RSM optimization. Renew. Energy 2019, 135, 1-9. [CrossRef]

68. Pizarro, A.V.L.; Park, E.Y. Lipase-catalyzed production of biodiesel fuel from vegetable oils contained in waste activated bleaching earth. Process. Biochem. 2003, 38, 1077-1082. [CrossRef]

69. Robles-Medina, A.; González-Moreno, P.A.; Esteban-Cerdán, L.; Molina-Grima, E. Biocatalysis: Towards ever greener biodiesel production. Biotechnol. Adv. 2009, 27, 398-408. [CrossRef] [PubMed] 
70. Sarno, M.; Iuliano, M. Active biocatalyst for biodiesel production from spent coffee ground. Bioresour. Technol. 2018, 266, 431-438. [CrossRef] [PubMed]

71. Yagiz, F.; Kazan, D.; Akin, A.N. Biodiesel production from waste oils by using lipase immobilized on hydrotalcite and zeolites. Chem. Eng. J. 2007, 134, 262-267. [CrossRef]

72. Lee, J.H.; Lee, J.H.; Kim, J.S.; Yoo, H.Y.; Park, C.; Kim, S.W. Biodiesel production by lipases co-immobilized on the functionalized activated carbon. Bioresour. Technol. Rep. 2019, 7, 1-8. [CrossRef]

73. Ferrero, G.O.; Faba, E.M.S.; Rickert, A.A.; Eimer, G.A. Alternatives to rethink tomorrow: Biodiesel production from residual and non-edible oils using biocatalyst technology. Renew. Energy 2020, 150, 128-135. [CrossRef]

74. Rabie, A.M.; Shaban, M.; Abukhadra, M.R.; Hosny, R.; Ahmed, S.A.; Negm, N.A. Diatomite supported by CaO/MgO nanocomposite as heterogeneous catalyst for biodiesel production from waste cooking oil. J. Mol. Liq. 2019, 279, 224-231. [CrossRef]

75. Bhatia, S.K.; Gurav, R.; Choi, T.R.; Kim, H.J.; Yang, S.Y.; Song, H.S.; Park, J.Y.; Park, Y.L.; Han, Y.H.; Choi, Y.K.; et al. Conversion of waste cooking oil into biodiesel using heterogeneous catalyst derived from cork biochar. Bioresour. Technol. 2020, 302, 1-6. [CrossRef] [PubMed]

76. Ambat, I.; Srivastava, V.; Iftekhar, S.; Haapaniemi, E.; Sillanpää, M. Effect of different co-solvents on biodiesel production from various low-cost feedstocks using Sr-Al double oxides. Renew. Energy 2020, 146, 2158-2169. [CrossRef]

77. Diamantopoulos, N.; Panagiotaras, D.; Nikolopoulos, D. Comprehensive review on the biodiesel production using solid acid heterogeneous catalysts. J. Thermodyn. Catal. 2015, 6, 1-8. [CrossRef]

78. Konwar, L.J.; Das, R.; Thakur, A.J.; Salminen, E.; Mäki-Arvela, P.; Kumar, N.; Mikkola, J.P.; Deka, D. Biodiesel production from acid oils using sulfonated carbon catalyst derived from oil-cake waste. J. Mol. Catal. A Chem. 2014, 388-389, 167-176. [CrossRef]

79. Lou, W.Y.; Zong, M.H.; Duan, Z.Q. Efficient production of biodiesel from high free fatty acid-containing waste oils using various carbohydrate-derived solid acid catalysts. Bioresour. Technol. 2008, 99, 8752-8758. [CrossRef]

80. Yaşar, F. Biodiesel production via waste eggshell as a low-cost heterogeneous catalyst: Its effects on some critical fuel properties and comparison with CaO. Fuel 2019, 255, 1-6. [CrossRef]

81. Abdullah, S.H.Y.S.; Hanapi, N.H.M.; Azid, A.; Umar, R.; Juahir, H.; Khatoon, H.; Endut, A. A review of biomass-derived heterogeneous catalyst for a sustainable biodiesel production. Renew. Sustain. Energy Rev. 2017, 70, 1040-1051. [CrossRef]

82. Nath, B.; Kalita, P.; Das, B.; Basumatary, S. Highly efficient renewable heterogeneous base catalyst derived from waste Sesamum indicum plant for synthesis of biodiesel. Renew. Energy 2020, 151, 295-310. [CrossRef]

83. Marwaha, A.; Rosha, P.; Mohapatra, S.K.; Mahla, S.K.; Dhir, A. Waste materials as potential catalysts for biodiesel production: Current state and future scope. Fuel Processing Technol. 2018, 181, 175-186. [CrossRef]

84. Galadima, A.; Muraza, O. Waste materials for production of biodiesel catalysts: Technological status and prospects. J. Clean. Prod. 2020, 263, 1-17. [CrossRef]

85. Chatterjee, A.; Hu, X.; Lam, F.L.-Y. Modified coal fly ash waste as an efficient heterogeneous catalyst for dehydration of xylose to furfural in biphasic medium. Fuel 2019, 239, 726-736. [CrossRef]

86. Shabani, J.M.; Babajide, O.; Oyekola, O.; Petrik, L. Synthesis of hydroxy sodalite from coal fly ash for biodiesel production from waste-derived maggot oil. Catalysts 2019, 9, 1052. [CrossRef]

87. Ren, X.; Qu, R.; Liu, S.; Zhao, H.; Wu, W.; Song, H.; Zheng, C.; Wu, X.; Gao, X. Synthesis of zeolites from coal fly ash for removal of harmful gaseous pollutants: A review. Aerosol Air Qual. Res. 2020, 20, 1127-1144. [CrossRef]

88. Tiwari, M.K.; Bajpai, S.; Dewangan, U.K.; Tamrakar, R.K. Suitability of leaching test methods for fly ash and slag: A review. J. Radiat. Res. Appl. Sci. 2015, 8, 523-537. [CrossRef]

89. Ram, L.; Masto, R. Fly ash for soil amelioration: A review on the influence of ash blending with inorganic and organic amendments. Earth Sci. Rev. 2013, 128, 52-74. [CrossRef]

90. Dwivedi, A.; Jain, M.K. Fly ash-Waste management and overview: A review. Recent Res. Sci. Technol. 2014, 6, 30-35.

91. Go, Y.W.; Yeom, S.H. Fabrication of a solid catalyst using coal fly ash and its utilization for producing biodiesel. Environ. Eng. Res. 2018, 24, 324-330. [CrossRef]

92. Nurfitri, I.; Maniam, G.P.; Hindryawati, N.; Yusoff, M.M.; Ganesan, S. Potential of feedstock and catalysts from waste in biodiesel preparation: A review. Energy Convers. Manag. 2013, 74, 395-402. [CrossRef]

93. Ayoob, A.K.; Fadhil, A.B. Valorization of waste tires in the synthesis of an effective carbon based catalyst for biodiesel production from a mixture of non-edible oils. Fuel 2020, 264, 1-13. [CrossRef]

94. Ibrahim, M.L.; Khalil, N.N.A.N.A.; Islam, A.; Rashid, U.; Ibrahim, S.F.; Mashuri, S.I.S.; Taufiq-Yap, Y.H. Preparation of Na2O supported CNTs nanocatalyst for efficient biodiesel production from waste-oil. Energy Convers. Manag. 2020, 205, 1-8. [CrossRef]

95. Bastos, R.R.C.; Corrêa, A.P.d.; da Luz, P.T.S.; Filho, G.N.d.; Zamian, J.R.; da Conceição, L.R.V. Optimization of biodiesel production using sulfonated carbon-based catalyst from an amazon agro-industrial waste. Energy Convers. Manag. 2020, 205, 1-12. [CrossRef]

96. Mardhiah, H.H.; Ong, H.C.; Masjuki, H.H.; Lim, S.; Pang, Y.L. Investigation of carbon-based solid acid catalyst from Jatropha curcas biomass in biodiesel production. Energy Convers. Manag. 2017, 144, 10-17. [CrossRef]

97. Faria, D.N.; Cipriano, D.F.; Schettino, M.A., Jr.; Neto, Á.C.; Cunha, A.G.; Freitas, J.C. Na, Ca-based catalysts supported on activated carbon for synthesis of biodiesel from soybean oil. Mater. Chem. Phys. 2020, 249, 1-9. [CrossRef]

98. Lázaro, M.J.; Ascaso, S.; Pérez-Rodríguez, S.; Calderón, J.C.; Gálvez, M.E.; Nieto, M.J.; Moliner, R.; Boyano, A.; Sebastián, D.; Alegre, C.; et al. Carbon-based catalysts: Synthesis and applications. Comptes Rendus Chim. 2015, 18, 1229-1241. [CrossRef] 
99. Narowska, B.; Kułażyński, M.; Łukaszewicz, M.; Burchacka, E. Use of activated carbons as catalyst supports for biodiesel production. Renew. Energy 2019, 135, 176-185. [CrossRef]

100. Rocha, P.D.; Oliveira, L.S.; Franca, A.S. Sulfonated activated carbon from corn cobs as heterogeneous catalysts for biodiesel production using microwave-assisted transesterification. Renew. Energy 2019, 143, 1710-1716. [CrossRef]

101. Guan, Q.; Li, Y.; Chen, Y.; Shi, Y.; Gu, J.; Li, B.; Miao, R.; Chen, Q.; Ning, P. Sulfonated multi-walled carbon nanotubes for biodiesel production through triglycerides transesterification. RSC Adv. 2017, 7, 7250-7258. [CrossRef]

102. Zhang, D.; Wei, D.; Ding, W.; Zhang, X. Carbon-based nanostructured catalyst for biodiesel production by catalytic distillation. Catalysis 2014, 43, 121-125. [CrossRef]

103. Clohessy, J.; Kwapinski, W. Carbon-based catalysts for biodiesel production-A review. Appl. Sci. 2020, 10, 918. [CrossRef]

104. Ghazanfari, J.; Najafi, B.; Ardabili, S.F.; Shamshirband, S. Limiting factors for the use of palm oil biodiesel in a diesel engine in the context of the ASTM standard. Cogent Eng. 2017, 4, 1-17. [CrossRef]

105. Specification for Biodiesel (B100)-ASTM D6751-07b 9. Available online: https://www.glycerintraders.com/ASTM\%206751\%2 0spec.pdf (accessed on 18 January 2022).

106. Biodiesel Standards. Available online: https://www.biofuelsystems.com/biodiesel/specification.htm (accessed on 25 January 2022).

107. Demirbas, A. Characterization of biodiesel fuels. Energy Sources Part A 2009, 31, 889-896. [CrossRef]

108. Karmakar, R.; Kundu, K.; Rajor, A. Fuel properties and emission characteristics of biodiesel produced from unused algae grown in India. Pet. Sci. 2018, 15, 386-395. [CrossRef]

109. Degfie, T.A.; Mamo, T.T.; Mekonnen, Y.S. Optimized biodiesel production from waste cooking oil (WCO) using calcium oxide (CaO) nanocatalyst. Sci. Rep. 2019, 9, 1-8. [CrossRef] [PubMed]

110. Meng, X.; Chen, G.; Wang, Y. Biodiesel production from waste cooking oil via alkali catalyst and its engine test. Fuel Processing Technol. 2008, 89, 851-857. [CrossRef]

111. Eevera, T.; Rajendran, K.; Saradha, K.S. Biodiesel production process optimization and characterization to assess suitability of product for varied environmental conditions. Renew. Energy 2009, 34, 762-765. [CrossRef]

112. Farid, M.A.A.; Roslan, A.M.; Hassan, M.A.; Hasan, M.Y.; Othman, M.R.; Shirai, Y. Net energy and techno-economic assessment of biodiesel production from waste cooking oil using a semi-industrial plant: A Malaysia perspective. Sustain. Energy Technol. Assess. 2020, 39, 1-11. [CrossRef]

113. Ogunkunle, O.; Ahmed, N.A. A review of global current scenario of biodiesel adoption and combustion in vehicular diesel engines. Energy Rep. 2019, 5, 1560-1579. [CrossRef]

114. Tabatabaei, M.; Aghbashlo, M.; Dehhaghi, M.; Panahi, H.K.S.; Mollahosseini, A.; Hosseini, M.; Soufiyan, M.M. Reactor technologies for biodiesel production and processing: A review. Prog. Energy Combust. Sci. 2019, 74, 239-303. [CrossRef]

115. Statistical Release (Stats SA). Available online: http://www.statssa.gov.za/publications/P0302/P03022021.pdf (accessed on 28 October 2021).

116. Statistical Release (Stats SA). Available online: http:/ / www.statssa.gov.za/?p=12056 (accessed on 18 May 2020).

117. Fawaz, E.G.; Salam, D.A. Preliminary economic assessment of the use of waste frying oils for biodiesel production in Beirut, Lebanon. Sci. Total Environ. 2018, 637-638, 1230-1240. [CrossRef]

118. Araujo, V.K.W.S.; Hamacher, S.; Scavarda, L.F. Economic assessment of biodiesel production from waste frying oils. Bioresour. Technol. 2010, 101, 4415-4422. [CrossRef]

119. Biofuels Industrial Strategy. South Africa. December 2007. Available online: http://www.energy.gov.za/files/esources/ renewables/biofuels_indus_strat.pdf(2).pdf (accessed on 17 May 2020).

120. Van Zyl, W.H.; Prior, B.A. Chair of Energy Research: Biofuels. 2009. Available online: http://academic.sun.ac.za/biofuels/ media\%20info/South\%20Africa\%20Biofuels\%20May\%202009\%20Progress\%20Report.pdf (accessed on 18 May 2020).

121. Yearbook 2018/2019. Government Communications and Information Systems. South Africa. Available online: https://www.gcis. gov.za/south-africa-yearbook-201819 (accessed on 18 May 2020).

122. Mineral and Petroleum Resources Development Act No. 28 of 2002. South Africa. Available online: https://www.gov.za/sites/ default/files/gcis_document/201409/a28-020.pdf (accessed on 18 May 2020).

123. The Constitution of the Republic of South Africa. 1996. Available online: http://www.saflii.org/za/legis/num_act/cotrosa19964 23/ (accessed on 22 January 2020).

124. National Energy Act No. 34 of 2008. South Africa. Available online: https://www.gov.za/sites/default/files/gcis_document/20 1409/316381263.pdf (accessed on 17 May 2020).

125. National Environmental Management Waste Act 59 of 2008. South Africa. Available online: http://www.saflii.org/za/legis/ consol_reg/fsfcapoafwmltart1085.pdf (accessed on 17 May 2020).

126. Directorate. Overview of the Petrol and Diesel Market in South Africa between 2007 and 2016; Energy Data Collection, Management and Analysis 2017; Department of Energy: Pretoria, South Africa, 2017; ISBN 978-1-920435-11-0.

127. National Development Plan 2030. South Africa. Available online: https:/ /www.gov.za/issues/national-development-plan-2030 (accessed on 17 May 2020).

128. Government Notices, Department of Mineral Resources and Energy. Pretoria, South Africa. 7 February 2020. Available online: http:/ / www.energy.gov.za/files/policies/petroleum/Biofuels-Regulatory-Framework-and-National-Biofuels-FeedstockProtocol.pdf (accessed on 17 May 2020). 